\title{
THE IMPLEMENTATION OF THE CARE-PROTECT (PEDULILINDUNGI) APPLICATION: THE ECONOMIC IMPACT AND CONSTRAINTS FACED
}

\section{Antonius Alijoyo, Erna Haerani}

Parahyangan Catholic University, Bandung ${ }^{1}$, LIKMI College of Management and Computers, Bandung ${ }^{2}$, Indonesia

Email: antonius.alijoyo@gmail.com,ernahaerani@gmail.com

\begin{tabular}{|c|c|}
\hline ARTICLE INFO & ABSTRACT \\
\hline 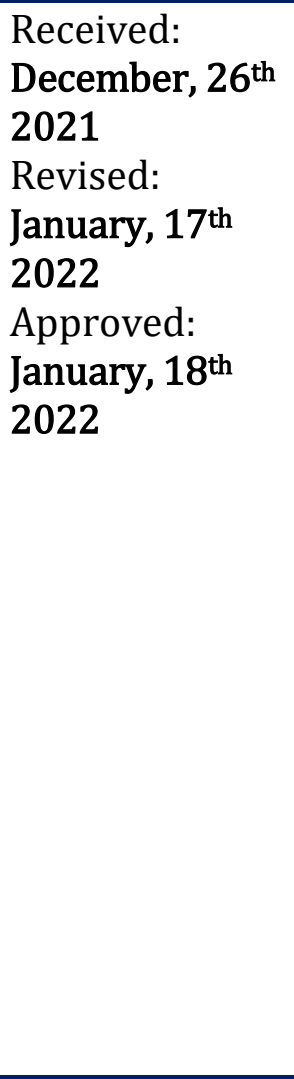 & $\begin{array}{l}\text { The COVID-19 pandemic has harmed the global economy. This is } \\
\text { due to the imposition of restrictions on social activities, which } \\
\text { have a negative impact on employment and subsequently harm } \\
\text { people's income and purchasing power. For this reason, the } \\
\text { government has issued Care-Protect (PeduliLindungi) application, } \\
\text { which functions to ensure that everyone active outside the house } \\
\text { has been vaccinated and is free from the virus. This study aims to } \\
\text { analyze the impact of the implementation of the PeduliLindungi } \\
\text { application on community and economic activities in Indonesia } \\
\text { and the obstacles faced in its implementation. This research was } \\
\text { carried out by following a systematic literature review research } \\
\text { method. The data were collected from previous studies that } \\
\text { examined the enforcement of PeduliLindungi applications. The } \\
\text { data were collected from the research results in articles } \\
\text { published in Sinta indexed journals. The collected data is then } \\
\text { analyzed using an interactive data analysis model. The results of } \\
\text { this study indicate that the PeduliLindungi application has some } \\
\text { impacts on the people's economy in Indonesia. In addition, this } \\
\text { research also identifies several obstacles faced by the community } \\
\text { and the government in implementing the Pedulilindungi } \\
\text { application. Detailed results regarding the positive and negative } \\
\text { impacts and constraints are discussed in this article, and some } \\
\text { suggestions based on the findings are also presented. }\end{array}$ \\
\hline KEYWORDS & $\begin{array}{l}\text { Community Economy, Covid-19, Pedulilindungi Application, } \\
\text { Systematic Literature Review }\end{array}$ \\
\hline (c) $(i)$ & $\begin{array}{l}\text { This work is licensed under a Creative Commons } \\
\text { Attribution-ShareAlike } 4.0 \text { International }\end{array}$ \\
\hline
\end{tabular}

How to cite:

E-ISSN:

Published by: https://greenpublisher.id/ 


\section{INTRODUCTION}

In an economy, various variables are used as economic stability, even most of the variables are used to increase a country's economic growth. In addition to the variable, there is a shock which is the meeting point for measuring the stability or instability of the economy (Carvallo \& Pagliacci, 2016); (Greenwood-Nimmo \& Tarassow, 2016). In general, macroeconomic studies aim to examine the relative importance of expansion and the dynamics of macroeconomic variables due to shocks. The phenomenon of shock has succeeded in attracting attention regarding the source and impact of an economic shock, both in an economy in one country and in another, which shows that there has been economic instability and deserves further exploration of its implications and impacts on the economy as a whole. The global Covid-19 outbreak has caused an economic shock, which has affected other macroeconomic variables, resulting in economic instability in various countries (Azomahou, Ndung'u, \& Ouédraogo, 2021).

The increasingly widespread of COVID-19 will prolong the period of the fall of the Asia Pacific economy. Australia, Hong Kong, Singapore, Japan, South Korea, and Thailand have been dragged into recession (Glocker \& Piribauer, 2021) (van der Wielen \& Barrios, 2021). The current slowdown in global economic development has had a significant impact on Indonesia's economic growth. Specifically for Indonesia, with the emergence of Covid-19, the Indonesian government has begun to emphasize that people are advised not to do activities outside their homes to avoid the increasing spread of Covid-19 (Irawan et al., 2020; Ulhaq et al., 2020). In contrast to other countries that have locked down, the Indonesian government with a policy of social distancing or LargeScale Social Restrictions is expected to reduce the impact of the economic crisis. This policy affects the economic activities of the people in Indonesia by limiting the space for people to move, not to mention the number of employees who have to be laid off and even dismissed from work by companies with reasons to cover losses that continue to grow (Mardiansyah, 2020).

Furthermore, the spread of Covid-19 can then be seen from two different economic points of view, namely supply and demand. From the demand side, the Covid19 pandemic reduced the consumption sector, travel, and transportation activities, as well as increased transportation and trade costs (Ben Hassen et al., 2021)(Ben Hassen et al., 2021; Cavallo et al., 2020; Cruz-Cárdenas et al., 2021). Meanwhile, from the supply side, there was a contraction in worker/labor productivity, a decline in investment and funding activities, and disruption of the global value chain (Mofijur et al., 2021). From the consumption side, people's consumption patterns due to the spread of Covid-19 will automatically change. People will tend not to do travel or tourism activities and are more likely to increase consumption of necessities that are considered necessary in anticipation of restrictions on human movement (Béné et al., 2021).

The impact of the Covid 19 pandemic on Indonesia's macro conditions can be seen from several events. In April 2020, around 1.5 million employees were laid off (City et al., 2021; Zubaidi et al., 2020). Second, the air service sector lost revenue of around IDR 207 billion in lost revenue, of which around IDR 48 billion lost revenue came from Chinese airlines (Panday, 2020). According to the Indonesian Hotel and Restaurant Association that there has been a decline in hotel occupancy rates in Indonesia by $50 \%$. The Coronavirus affects hotels, restaurants, and retail entrepreneurs who support tourism. The decline in hotel occupancy affected the continuity of the hotel business in the long term. The lack of tourists also impacts restaurants, where most consumers are tourists. The weakening tourism sector also had an impact on the retail industry. The spread of Covid 19 also affects the investment, trade, micro, small and medium enterprises sector 
because when tourists visit tourist attractions, these tourists typically make requests or buy souvenirs. Eighth, inflation occurred in March 2020 of $2.96 \%$ year on year (YoY), with rising prices for gold jewelry and some food prices, which experienced quite a drastic increase.

Efforts have been made to combat Covid-19 through technology, one of which is the creation of Covid-19 prevention applications. Indonesia developed a local application called Care-Protect (PeduliLindungi). This application utilizes personal data and a Bluetooth network connection that functions to track location and record user activity to prevent the spread of Covid-19. This application notifies developers and users if contact is detected with a positive Covid-19 patient or person under surveillance. With this application, the government provides an opportunity for healthy people to continue their activities to carry out economic activities. This study aims to see how the impact of the application of this PeduliLindungi application on the economy in Indonesia. It is hoped that the findings in this study can be used as input for the development of PeduliLindungi applications and assist the government in taking appropriate policies to maintain public health and safety without neglecting the economic aspect.

\section{RESEARCH METHOD}

The researcher conducted this study by following the Systematic Literature Review approach to achieve the study's objective. The researchers did fours steps during the study, namely designing the review, conducting the review, analyzing, and writing the review (2019). The researcher selected Sinta indexed national journals to collect the intended data. Furthermore, the journal that published the article was verified on the Sinta website to ensure that Sinta indexes the national journal. The selected articles are published from 2020 to 2021, which discuss the implementation of the PeduliLindungi application. The collected data was then analyzed qualitatively with an interactive model analysis technique consisting of three stages, data reduction, data display, and conclusion drawing/verification (Miles et al., 2014).

\section{RESULT AND DISCUSSION}

The discussion is started with an explanation of the PeduliLindungi application. Then, it is specifically followed by the identification of the impacts of the implementation of application and its obstacles.

\section{PeduliLindungi Application}

The PeduliLindungi application is stipulated through the Decree of the Minister of Communication and Information Number 171 of 2020 as amended by the Decree of the Minister of Communication and Informatics Number 253 of 2020 concerning Amendments to the Decree of the Minister of Communication and Information Technology Number 171 of 2020 concerning the Determination of the PeduliLindungi Application in the Framework of Implementing Health Surveillance for Handling Corona Virus Disease 2019 (Covid-19). As an application that is used in the implementation of health surveillance by the government in dealing with the spread of Covid-19, the PeduliLindungi application must continue to be maintained because it is beneficial for the community in tracing, tracking, and warning (warning and fencing) Covid-19 (Nurhidayati, Sugiyah, \& Yuliantari, 2021). 
The PeduliLindungi application is still being developed by completing various features that make it easier for people in the new normal era. One of which is the addition of the e-passport feature as a travel document in the form of user data that has been declared negative for the Covid-19 test. The government has also improved the PeduliLindungi application to use non-smartphone devices. So later, this application can also be used by telephone users via SMS technology (Kementerian Kesehatan, 2021). In addition, the government has also created a monitoring dashboard that is used for tracing, tracking, and fencing. In this case, dashboard tracing and tracking to see users who have close contact with positive patients. Fencing dashboard to see the movement of people in self-quarantine. Monitoring is available at the Ministry of Health, which can monitor patients and self-quarantining people.

This application was created to identify people who have been in close contact with people who have tested positive for Covid-19 or Patients Under Surveillance and People Under Surveillance (Herdiana, 2021). The user can remember his travel history and with whom he made contact through the application. In addition, this application can also make it easier for people who are active outside the home to be aware of virus-carrying couriers. As long as there is a record, all positive, recovered, under monitoring, or healthy people provide information about themselves. As for how the PeduliLindungi application works, people who have downloaded it are asked to activate Bluetooth on their cellphones. It is hoped that with the Bluetooth condition being active, the application periodically identifies other PeduliLindungi users' phones, which are in the Bluetooth radius, to record their location and contact time.

The mechanism is that adjacent cellphones will then record each other's anonymous IDs, the Anonymous ID data will be stored within 14 days, so that if someone is declared sick by a health worker (not by an application) and inputted into the database system, then the system will filter out other anonymous IDs that have been in contact with Covid-19 sufferers in the last 14 days (Iskak, Rusydi, Hutauruk, Chakim, \& Ahmad, 2021). The PeduliLindungi application was created by the government to mitigate the Covid-19 disaster in Indonesia. In addition to being able to provide information on the number of people exposed to Covid per area, the PeduliLindungi application also offers several important things related to the Covid-19 disaster, such as the existence of an independent health check feature through a third-party application that has been provided and some health tips in preventing the spread of Covid-19 in the community.

If the community members are going to access public facilities, they must scan the barcode/QR Code that is available at the gate before entering the public facility (Afiana, Yunita, Oktaviana, \& Hasanah, 2020). Public facility services or are refused, for example, because the community is in a state of Covid-19 self-isolation, which requires them to remain in self-isolation. Public facilities that will carry out the scanning process as a screening process for citizens through the PeduliLindungi application must be public facilities whose implementation has been allowed and regulated through laws and regulations, such as shopping center/mall operations. In this context, the government will ensure that only the management of public facilities that have been given operational permits can implement the PeduliLindungi application (Robin \& Priscila, 2021).

\section{The impact of the implementation of PeduliLindungi applications}

The obligation to show a Covid-19 vaccination certificate as one of the requirements for activities in public spaces has been implemented in several countries. China, for example, applies full vaccination requirements to be able to go to school and enter public spaces such as hospitals and supermarkets (XUE, 2021). Israel introduced the green pass as a travel condition (Gewirtz-Meydan, Mitchell, Shlomo, Heller, \& 
Greenstein, 2021). Several European Union countries such as France, Austria, Denmark, and Switzerland have also implemented a vaccination card (digital green certificate) along with a negative Covid-19 test result as a condition for enjoying public spaces, from visits to cultural events, sports, to restaurants and cafes (de Figueiredo, Larson, \& Reicher, 2021; Hernández, Calina, Poulas, Docea, \& Tsatsakis, 2021). Meanwhile, in Indonesia, a Covid-19 vaccination certificate is given when someone has vaccinated both the first and second doses, which can be downloaded independently through the PeduliLindungi website and application.

From the data that has been collected, little information is obtained regarding the economic impact caused by the implementation of the PeduliLindungi application. However, in general, a screening process for people who will use public facilities is expected to reduce the potential for Covid-19 transmission in public spaces (Putri \& Hamzah, 2021). On the other hand, the screening process for people who access public facilities through the PeduliLindungi application can also provide other benefits such as creating community economic productivity in public areas, such as in shopping centers while still implementing health protocols, so that it is expected to be able to create benefits that have a dual effect on the community and various aspects of community life.

The use of the PeduliLindungi application has been directly benefited by PT. Asahi. The company's operations run smoothly because all employees can work in the company environment to achieve the production capacity target (Kementerian Perindustrian Republik Indonesia, 2021). In addition, with the PeduliLindungi application, companies can be even more selective in screening guests who come to the company. In other words, this application ensures the safety of the customers and also the employee. Feeling secure will help the company to work effectively and at the same time for the customers it will improve their purchase intention, especially when they buy food or do traveling (Abdullah, Dias, Muley, \& Shahin, 2020; Lai et al., 2021; Jiabao Lin et al., 2021; Smith, Machalaba, Seifman, Feferholtz, \& Karesh, 2019).

\section{Obstacles in implementing the PeduliLindungi application}

The obstacle that the government feels in socializing the use of the PeduliLindungi application is that the use of the PeduliLindungi application is currently not fully optimal because the relevant agencies still hamper the data entry process for Covid-19 positive people, and the number of users of the PeduliLindungi application still needs to be increased. For this reason, so that the effectiveness of the PeduliLindungi application can be further improved, enforcement from the government is needed, including; First, it obliges the ASN (State Civil Apparatus), BUMN employees to use the digital travel permits that exist in PeduliLindungi. Second, prepare field officers to verify digital travel permits at PeduliLindungi. Third, train personnel to verify requests for travel permits. Fourth, the process of checking workers, employees by building security to download and install the PeduliLindungi application for cellular devices before being allowed to enter the building. Fifth, the process of checking visitors to malls or tourist areas by security to install the PeduliLindungi application before being allowed to enter the mall or tourist area.

The government is working together to invite the public to download the application to make it easier for the government to track the spread of Covid in the country, the socialization is driven from civil servants to civil servants who are required to download the application to the wider community, but the number of downloaders of the PeduliLindungi application as of July 26, 2020, only reached 4,261,815. Compared with Indonesia's population and the number of smartphone users, the number of users of the PeduliLindungi application is still very small (Nurhidayati et al., 2021). 
Security guarantees from hacking the PeduliLindungi application are also part of the issues that arise (Olivia, Rosadi, \& Permata, 2020). An essential issue in the system aspect is how people's data vaccinated against Covid-19 can be kept confidential when stored in the PeduliLindungi application system, which can harm the citizens holding the identity card. Another issue in the system aspect is how the PeduliLindungi application can be used easily and quickly; this is important because people entering public facilities in large numbers are likely to create a crowd. This is experienced in several public facilities, such as when entering Jakarta's capital city's train station and the mall. Community activities cause crowds that are feared to be a medium for spreading Covid19.

From the government side, guaranteeing the responsibility for managing the PeduliLindungi application is necessary. It must be specified in the laws and regulations if there is an error or malfunction. If there is a hack on the PeduliLindungi site, which agency should be responsible and which official will bear the risk from the PeduliLindungi application should be assigned. With these problems, this is important in addition to being accountable for the implementation of the PeduliLindungi application and providing a sense of public trust in the management of the PeduliLindungi application. Another issue is coordination and accountability between institutions in the management of the PeduliLindungi application, where there is a disagreement between the Ministry of Health and the Ministry of Communication and Information, thus raising questions about how the collaboration has been built so far and the accountability of the institution that manages the PeduliLindungi application.

From the community side, the main target of implementing the PeduliLindungi application is the community, so that the community's response to the PeduliLindungi application is very important to pay attention to. The first issue that comes from the community aspect is the accuracy of data on people who have been vaccinated against Covid-19. This is based on several cases where community members claim that their population numbers have been used by other parties so that these residents cannot have access to the Covid-19 vaccination. This condition must, of course, be a concern so that people who have been vaccinated are citizens of the community according to their population numbers. In addition to the community's right to get the Covid-19 vaccine, it also concerns the safety of citizens from being exposed to Covid-19 because they have not been vaccinated.

Table 1. The Summary of the Impact and the Obstacles on the PeduliLindungi

Application Implementation

\begin{tabular}{|l|l|}
\hline \multicolumn{1}{|c|}{ Aspect } & \multicolumn{1}{c|}{ Result } \\
\hline Impact & Prevent the spread of the Covid-19 \\
\cline { 2 - 2 } & Protect the customers and the employees \\
\cline { 2 - 2 } & Improve the company productivity \\
\cline { 2 - 2 } & Ensure the security of travelers \\
\cline { 2 - 2 } & Provide valid information on the Covid-19 issues \\
\hline Obstacles & Building people trust to apply the application \\
\cline { 2 - 2 } & The number of the application users is still low \\
\cline { 2 - 2 } & $\begin{array}{l}\text { Not all Indonesian people have a smartphone that can run the } \\
\text { application }\end{array}$ \\
\cline { 2 - 2 } & A regulation that regulate the use of the application \\
\cline { 2 - 2 } & Fake vaccinated certificate \\
\cline { 2 - 2 } & Discrimination for those who are not vaccinated \\
\hline
\end{tabular}




\section{Recommendation}

The government has a strategic role in improving the quality of the PeduliLindungi application. This includes improving the security system in the PeduliLindungi application so that it is safe from hacking attempts that will harm many parties. It is also necessary to regulate how state institutions manage the PeduliLindungi application so that they have clear rights and obligations if in the future problems arise that demand government accountability for the use of the PeduliLindungi application. Improvement efforts in the context of using the PeduliLindungi application are not only concerned with the security and clarity of the management agency, but also solutions such as what kind of public access to the PeduliLindungi application, which empirically does not have an electronic device, considering that access to public facilities is a citizen's right. Some efforts will not lead to discriminatory attitudes to people who do not have electronic devices to access public facilities. The community in implementing the PeduliLindungi application has an important role, and this is because the target object of the PeduliLindungi application policy is the community. Hence, the community's active role is the key to the success of the PeduliLindungi application. Vice versa when the community is passive and has no desire to participate, the PeduliLindungi application tends to fail. In a larger context, the successful implementation of the PeduliLindungi application will reflect the community's attitude in supporting the Covid-19 response policy. Based on these recommendations, it is hoped that the PeduliLindungi application will become a policy instrument for dealing with Covid-19 that can effectively reduce the spread of Covid-19, especially in social interaction in public spaces where citizens interact with one another.

\section{CONCLUSION}

From the results of this study, it can be concluded that there are not many studies that examine the impact of the implementation of the PeduliLindungi application on the economy in Indonesia. However, in general, from the data that has been collected, it is found that this application can make companies operate again and reduce the risk of the spread of Covid-19 in the company area so that workers can work optimally. However, in terms of obstacles, it can be conveyed that there are various obstacles faced by the government and the community, ranging from technical problems, the availability of smartphone devices, and problems with criminal acts. This research is only limited to identifying the qualitative impact of the PeduliLindungi application on the economy in Indonesia and the issues that arise in Indonesia. Further studies are needed to quantitatively identify the effects of the PeduliLindungi application on the economy so that the impact can be measured and the research results can be generalized.

\section{REFERENCES}

Abdullah, Muhammad, Dias, Charitha, Muley, Deepti, \& Shahin, Md. (2020).

Exploring the impacts of COVID-19 on travel behavior and mode preferences. Transportation Research Interdisciplinary Perspectives, 8 , 100255. https://doi.org/https://doi.org/10.1016/j.trip.2020.100255

Afiana, Fiby Nur, Yunita, Ika Romadoni, Oktaviana, Luzi Dwi, \& Hasanah, Uswatun. (2020). Pelatihan Teknis Penggunaan Aplikasi PeduliLindungi Guna Melacak Penyebaran COVID-19. JPMM (Jurnal Pengabdian Mitra Masyarakat), 2(2), 98-106. 
Azomahou, Théophile T., Ndung'u, Njuguna, \& Ouédraogo, Mahamady. (2021). Coping with a dual shock: The economic effects of COVID-19 and oil price crises on African economies. Resources Policy, 72, 102093.

Carvallo, Oscar, \& Pagliacci, Carolina. (2016). Macroeconomic shocks, bank stability and the housing market in Venezuela. Emerging Markets Review, 26, 174-196.

de Figueiredo, Alexandre, Larson, Heidi J., \& Reicher, Stephen D. (2021). The potential impact of vaccine passports on inclination to accept COVID-19 vaccinations in the United Kingdom: Evidence from a large cross-sectional survey and modeling study. EClinicalMedicine, 40, 101109. https://doi.org/https://doi.org/10.1016/j.eclinm.2021.101109

Gewirtz-Meydan, Ateret, Mitchell, Kim, Shlomo, Yaniv, Heller, Or, \& Greenstein, Michal Weiss. (2021). COVID-19 among youth in Israel: Correlates of decisions to vaccinate and reasons for refusal. Journal of Adolescent Health. https://doi.org/https://doi.org/10.1016/j.jadohealth.2021.11.016

Glocker, Christian, \& Piribauer, Philipp. (2021). Digitalization, retail trade and monetary policy. Journal of International Money and Finance, 112, 102340.

Greenwood-Nimmo, Matthew, \& Tarassow, Artur. (2016). Monetary shocks, macroprudential shocks and financial stability. Economic Modelling, 56, 1124.

Herdiana, Dian. (2021). Aplikasi peduli lindungi: Perlindungan masyarakat dalam mengakses fasilitas publik di masa pemberlakuan kebijakan PPKM. Jurnal Inovasi Penelitian, 2(6), 103-111.

Hernández, Antonio F., Calina, Daniela, Poulas, Konstantinos, Docea, Anca Oana, \& Tsatsakis, Aristidis M. (2021). Safety of COVID-19 vaccines administered in the EU: Should we be concerned? Toxicology Reports, 8 , 871-879. https://doi.org/https://doi.org/10.1016/j.toxrep.2021.04.003

Iskak, Iskak, Rusydi, Muhammad Zuaim, Hutauruk, Roni, Chakim, Shoful, \& Ahmad, Wildan Ramdani. (2021). Meningkatkan Kesadaran Masyarakat Tentang Pentingnya Vaksinasi Di Masjid Al - Ikhlas, Jakarta Barat. Jurnal PADMA: Pengabdian Dharma Masyarakat, 1(3).

https://doi.org/10.32493/jpdm.v1i3.11431

Kementerian Kesehatan. (2021). Fitur PeduliLindungi bisa Diakses di Aplikasi Lain Mulai Oktober.

Kementerian Perindustrian Republik Indonesia. (2021). Tinjau Sektor Esensial, Kemenperin: Industri Rasakan Manfaat Aplikasi PeduliLindungi.

Lai, Shengjie, Ruktanonchai, Nick W., Carioli, Alessandra, Ruktanonchai, Corrine W., Floyd, Jessica R., Prosper, Olivia, Zhang, Chi, Du, Xiangjun, Yang, Weizhong, \& Tatem, Andrew J. (2021). Assessing the Effect of Global Travel and Contact Restrictions on Mitigating the COVID-19 Pandemic. Engineering, 7(7), 914-923. https://doi.org/https://doi.org/10.1016/j.eng.2021.03.017

Li, Shijie, Wang, Chunchun, Cai, Mingjie, Yang, Fang, Liu, Yanping, Chen, Jialin, Zhang, Peng, Li, Xin, \& Chen, Xiaobo. (2022). Facile fabrication of TaON/Bi2MoO6 core-shell S-scheme heterojunction nanofibers for boosting 
visible-light catalytic levofloxacin degradation and $\mathrm{Cr}$ (VI) reduction. Chemical Engineering Journal, 428, 131158.

Lin, Jiabao, Li, Ting, \& Guo, Jinyuan. (2021). Factors influencing consumers' continuous purchase intention on fresh food e-commerce platforms: An organic foods-centric empirical investigation. Electronic Commerce Research and Applications, 50, 101103.

Lin, Qingquan, Zeng, Guangyong, Yan, Guilong, Luo, Jianquan, Cheng, Xiaojie, Zhao, Ziyan, \& Li, Han. (2022). Self-cleaning photocatalytic MXene composite membrane for synergistically enhanced water treatment: Oil/water separation and dyes removal. Chemical Engineering Journal, 427, 131668.

Nurhidayati, Nurhidayati, Sugiyah, Sugiyah, \& Yuliantari, Kartika. (2021). Pengaturan Perlindungan Data Pribadi Dalam Penggunaan Aplikasi Pedulilindungi. Widya Cipta: Jurnal Sekretari Dan Manajemen, 5(1), 39-45. https://doi.org/10.31294/widyacipta.v5i1.9447

Olivia, Denindah, Rosadi, Sinta Dewi, \& Permata, Rika Ratna. (2020). Perlindungan data pribadi dalam penyelenggaraan aplikasi surveilans kesehatan pedulilindungi dan covidsafe di Indonesia dan Australia. DATIN: Law Journal, 1(2), 1-9.

Putri, Citra Eka, \& Hamzah, Radja Erland. (2021). Aplikasi Pedulilindungi Mitigasi Bencana Covid-19 Di Indonesia. Jurnal Pustaka Komunikasi, 4(1), 66-78. https://doi.org/10.32509/pustakom.v4i1.1321

Robin, Patricia, \& Priscila, Gabriela. (2021). Pengaisan Big Data \& Dunia Kesehatan: "Analisis Penyalahgunaan Big Data Dalam Usaha Pemerintah Indonesia Di Masa Pandemi Covid-19." Jurnal Public Corner Fisip Universitas Wiraraja, 16, 38-48.

Smith, Kristine M., Machalaba, Catherine C., Seifman, Richard, Feferholtz, Yasha, \& Karesh, William B. (2019). Infectious disease and economics: The case for considering multi-sectoral impacts. One Health, 7, 100080. https://doi.org/https://doi.org/10.1016/j.onehlt.2018.100080

van der Wielen, Wouter, \& Barrios, Salvador. (2021). Economic sentiment during the COVID pandemic: Evidence from search behaviour in the EU. Journal of Economics and Business, 115, 105970.

XUE, Janet Hui. (2021). Algorithmic Vulnerability in Deploying Vaccination Certificates in the European Union and China. European Journal of Risk Regulation, 12(2), 332-342. https://doi.org/DOI: 10.1017/err.2021.32 